from fortilizer most commonly limits the efficiency with which the grass crop makes use of the other resources of its environment, and considerablo emphasis was placed on the advantages, both technical and economic, to be obtained from an increased use of nitrogen fertilizer. There was no evidence that the greater quantity of herbage obtained through the use of nitrogen fertilizer resulted in poorer quality. It was, however, emphasized that the application of nitrogen would only be cconomically effective if the whole system of management was adapted to it. All the papers, and the substantial contribution of those who opened tho discussions, are printed in full with tables and diagrams. There is also a summary of the gencral diseussion which concluded each session.

The sccond general meeting is to be held in France during May $22 \cdot 27,1967$, and the subject will be technical and economic evaluation of grassland at the level of the farm. In 1968 a symposium on hill land productivity will be held in Seotland.

C. R. Clemen't

\section{LOOKING AFTER ANIMALS}

The UFAW Handbook on the Care and Management of Laboratory Animals

Edited by the Staff of UFAW with the assistance of W. Lane Petter, A. N. Worden, Berton F'. Hill, J. S. Paterson and $H$. G. Vevers. Third edition. Pp. xvit 1015. (Edinburgh and London: E. and S. Livingstono, Ltd., in collaboration with UFAW, 1967.) $120 s$. not.

THE first edition of the UFAW Handbook on the care and management of laboratory animals appoared in 1947 and immediately became an important influence for the improvement of laboratory animal care. With this first edition it became a standard reference text, to be found and consulted in every laboratory whoro experimental animals are bred or kept. In view of this, each edition is studied for its content of new information and the lead it gives in this rapidly devoloping subjoct.

With this third edition the problems of collecting the contributions from sixty-five authors from ton countries became increasingly difficult, and the editors inform us that this cdition has bcen five years in preparation and then rapidly edited by the UFAW staff. Thus it is not sinrprising that this edition is no longer fully up to date or that the chapters thomselves differ greatly in both approach and factual content.

In the introduction Sir Peter Medawar sets out the aim: "The UFAW Handbook is aimed at senior animal-technicians and research workers using animals of a particular spccies for the first time".

The book itself is in four parts. Section 1 consists of general considerations and includes animal house design and equipment, where Dr. Lane Petter expands his own special contribution to this subject. ()ther chapters include general introductions to anuesthesia and outhanasia, hygieno, breeding methods, nutrition, germ-free and specifie pathogen-freo animals. The chnpters on tho animal technician and on handling animals are excellent surveys and this section is packed with the basic information for general laboratory animal care and should be read by everyone designing a new animal house or renovating an old one.

Sections 2, 3 and 4 deal with individual spocies and groups of animals: rodents, lagomorphs and insectivores; enrnivores, ungulates and primates; birds, poikilotherms and invertebrates respectively. These chapters contain a groat deal of factual information as well as the authors' opinions. Somo aro not directly applicable, for cages for chimpanzees aro likely to be different in the United Kingdom from those used in Florida.

New species which aro now firmly established as laboratory animals includo the coturnuix quail, gerbils and African baboon, while attention is given to insectivores with an excellent chaptor on the hedgehog and notes on the shrews, but nothing as yet on the marmoset or squirrel monkey. It is questionable if tho larger domestic animals, cows and horses should be included; few are used and much information is available elsewhero.

While every usor of laboratory animals will turn to this volume as a first source of information, it is in these chapters on individual species that the purpose of this volume is unclear. Should it provide a general introduction, but with full references, or contain full dotails? And here the treatmont varios between these two ideas. A standard approach by the editors would have helpod. Notes on discases without further reference can be misloading and present a problem of where to turn for further information.

Gross errors scem few ; for example, Fig. 30 on page 123 is inverted. The format in some cases wastos space, as on page 38 where a heading and two lines of text occupy 1.5 in. of pago. Perhaps too many of the old illustrations have beon rotained; most purchasers of this edition will have the older one to refor to: a stainproof cover would be: useful, as would stronger binding, to stand the constant. hard use this book usually receives.

A short index is provided, but, as in the carlier volumes, it is no more satisfactory. For monkeys it lists the vervet, but not the other African species included in the text, Galago crassicaudatus is listed; but under Macaca it reads "see monkcys": while the only entry under Primates reads "personal safoty"!

In view of the long dolay in the preparation, and the uneven nature of the chapters in this edition, now is perhaps a good time to reviso this project and the aims of the finture editions.

In spite of these rather irritating faults, this volume is packed with reliable information, and the editors and UFAW are to be congratulated for undertaking this work, and for bringing together so many different contributors on the subject of laboratory animal care.

As with the carlier editions this remains the standard toxt, and necessary for all laboratories where experimental animals are bred and used.

M. LANCASTER

\section{USEFUL MUTATIONS}

\section{Mutations in Plant Breeding}

(Proceedings of a Panel on Co-ordination of Research on the Production and Use of Induced Mutations in Plant Trrceding, held in Vienna, 17-21 January, 1966. Panel Proceedings Sories.) Pp. 27l. (Vienna : Tritel. national Atomic Fnergy Agency; Iondon: H.M.S.O.. 1966.) 155 schillings; $42 s .4 d . ; \$ 6$.

IN his classic 1927 paper in Science, "Artificial Transmutation of the Gene," in which X-ray induced gene mutations were first described, H. J. Muller indicated the restrictions that were at that timo imposed on genetic rosearch by the infroquent origin of new genetic variation by muta. tion. He went on to point out that, "Modification of the innate nature of organisms, for more directly utilitarian purposes, has of course beon subject to these samo restrictions, and the practical breeder has hence been compelled to remain content with the more making of recombinations of the material already at hand, providen. tially supplemented, on raro and isolated oceasions, by an inexpected mutational windfall". Later in the same paper, in discussing the usefulness of X-ray trealments in genetical research, Muller also suggested that, " . . . for the practical breeder, it is hoped that the method will nltimately prove useful". Subsequent experience has justified the caution with which the optimism of this prognostication was tempered, for artifieially induced gonetic variation, giving agricultural bencfits, has only been incorporated in commercial orops in the presert decade. 